\title{
AEROBIC AND ANAEROBIC EFFICIENCY OF YOUNG FOOTBALL PLAYERS IN HALF-YEAR TRAINING PERIOD ESTIMATED BY LABORATORY METHODS
}

\author{
Urszula Szmatlan-Gabrys ${ }^{1}$, Mariusz Ozimek ${ }^{2}$, Marek Szczerbowski ${ }^{3}$ \\ Academy of Physical Education in Warsaw ${ }^{1}$, Warsaw, Academy of Physical Education in Cracow ${ }^{2}$, \\ Cracow, Academy of Physical Education in Katowice, Katowice, Poland
}

\begin{abstract}
Urszula Szmatlan-Gabrys. PhD in Biomedical sciences. Research worker at the Department of Pedagogics, Josef Pilsudski Academy of
\end{abstract} Physical Education. Research interests - sports science.

\begin{abstract}
The main of activities of football players during the game are involved in the group of speed-strength efforts and speed and short-time endurance efforts. The efforts first of all are based on anaerobic metabolism (95-98\%) which causes oxygen deficit, depending on the length of the activity.

The aim of the research was to determinate the value, structure and dynamics of efficiency of aerobic and anaerobic efforts of young football players in a half-year training cycle.

The research involved 9 competitors aged 16 years, and 18 competitors aged 17 years. The 1st examination was held at the beginning, 2nd - after 3 months and the 3rd one at the end of a 6-month training cycle. During the research we measured the changes in the cardiorespiratory system during the test of gradually increasing ergometric intensity and during the Wingate test, with the loads of 10-60 s. The lactate concentration in the blood was also measured.

The analysis of the research carried out in the group of 16-17 year-old football players showed the differentiated range of changes of the parameters characterizing the aerobic efficiency level. The aerobic work typical of the first training period does not stimulate the development of aerobic efficiency parameters of 16-17 year old football players. The intensification of sport loads (league games) in the field of aerobic efficiency level after 6 - 8 weeks of stabilization leads to essential (statistically significant) reduction of the parameters of $V O_{2 \max }$, and $V_{A T}$ as well as to the increase of \% $\mathrm{VO}_{2 \max }$ with simultaneous reduction of work intensity registered at the AT threshold.

The tendency of increasing of oxygen consumption level was noticed during the special preparation period when the essential part of training was directed to the development of football players'special endurance. Anaerobic alactic capacity increase $(p<0.001, p<0.01)$ was observed during the special and pre-start preparation periods. The start period was not favorable for the changes of all the parameters of the efficiency of football players.

The growth of parameters of maximal power and total work during short-time efforts was not observed. The parameters undergoing to periodical changes during the 6 month training cycle include: total work during Wingate test and the sum of total work activity during three 60 second efforts with a 60 second pause. The changes of lactic acid concentration in blood after 30-60 second efforts of maximal intensity in these estimations were substantiated.
\end{abstract}

Keywords: aerobic efficiency, anaerobic efficiency, training, football.

\section{INTRODUCTION}

$\mathrm{T}$ The main activities of football players during the game are involved in the group of speedstrength efforts and speed and short-time endurance efforts. The efforts first of all are based on anaerobic metabolism (95-98\%) which causes oxygen deficit, depending on the length of the activity. Aerobic transformations have relatively low contribution to metabolism during short activities of maximal and submaximal intensity. This fact does not mean that less attention has to be paid to the development of the efficiency of those activities in the training process of football players. The research shows that competitors representing the speedstrength and speed-endurance sport disciplines characterized by high level of aerobic efficiency, including football players, demonstrate better predispositions of realizing the maximal intensity efforts (Berger et al., 1982; Shepard, Astrand,1992; Reilly, 1994; Dintiman et al., 1997). The aerobic process plays the greatest role in the period of posteffort restitution caused by the exercises of anaerobic character, accelerating the lactates elimination 
from the blood and is the decisive parameter in the process of adaptation to the training loads when the training cumulating effect is observed (Chin et al., 1992; Shepard, Astrand, 1992; Catterall et al., 1993; Hrysomallis et al., 2002). When planning the sport training process the estimation of time limits for effort exercises, in which the dominating role is played by one of the processes mentioned above (anaerobic non-lactic acid efforts, anaerobic lactic acid efforts, mixed and aerobic efforts), is of basic significance (Wierchoszanskij, 1985).

The aim of the research was to determine the value, structure and dynamics of efficiency of aerobic and anaerobic efforts of young football players in a half-year training cycle.

\section{MATERIALS AND RESEARCH METHODS}

The research involved the competitors from Gwarek Zabrze sport club. The examined group included 9 competitors aged 16 years and 18 competitors aged 17 years. The average weight of the competitors was $65.23 \pm 7.03 \mathrm{~kg}$, and the average height was $173.8 \pm 7.36 \mathrm{~m}$. The training experience of the competitors was 4 to 7 years. The research was carried out during the 6-month training cycle (the 1st examination was at the beginning, the $2^{\text {nd }}-$ after 3 months, and the $3^{\text {rd }}-$ at the end of the 6 month training cycle) which consisted of the preparation period and the start period.

The following measurement instruments were used in the study: gas analyzer Oxycon (f. Jeager, Germany); registration by "on-line" system (from breath to breath) of $\mathrm{VO}_{2}, \mathrm{CO}_{2}, \mathrm{~V}_{\mathrm{E}}$ values; Systole frequency monitor, Polar Team Sport (Finland) (the registration of systole frequency was made at 5 second intervals); Running track LE 300C HP Cosmos allowing the smooth speed regulation (maximal speed of belt pass of $24 \mathrm{~km} / \mathrm{h}$ was not achieved by the examined sportsmen); the mechanical ergometer Monark-824E (Sweden) with on-line system registration of power and total work parameters by computer system with two electromagnetic sensors and computer program MCE v.4.5 (Institute of Sports, Warsaw).

During the research the following tests were carried out: the test of gradually increasing intensity $\left(\mathrm{VO}_{2 \max }, \mathrm{HR}_{\max }, \mathrm{V}_{\max }, \mathrm{HR}_{\mathrm{AT}}, \% \mathrm{VO}_{2 \max }\right)$, the ergometric Wingate test, the ergometric $60 \mathrm{~s}$ test $\left(\mathrm{P}_{\max 60}, \mathrm{~W}_{\text {TOT, }} \Delta \mathrm{LA}_{60}\right)$, the ergometric test $3 \times 60 \mathrm{~s}$ $\left(\Sigma \mathrm{W}_{\text {TOT3 }} \times 60\right)$, the ergometric $10 \mathrm{~s}$ test $\left(\mathrm{P}_{\max 10} \mathrm{~W}_{\text {TOT }}\right.$ 10), the ergometric $6 \times 10 \mathrm{~s}\left(\mathrm{~W}_{\text {TOT6 } \times 10}\right)$.
The measurement of lactate concentration (LA) in the blood was made by Dr Lange Cuvette LKM 140 photometric method demanding the use of standard reagents $f$. Dr Lange average (Germany). The blood samples were collected from preliminary warmed fingertips.

In the statistical analysis the average values of (x), standard deviation (SD), standard error, minimal and maximal values were estimated. The verification of consistence of sample distribution with theoretical distribution was made with the help of Kolmogorov-Smirnov test. The verification of normal distribution was carried out by the Shapiro-Wilk test. To compare the average values of measured parameters for two samples the t-Student test was used as well as the variations analysis for repeatable measurements. For post hoc variations analysis the comparison tests of related samples were used on the basis of Bonferroni correction. In order to examine the interdependence of several features the correlation analysis was applied. The results of this analysis were estimated using Pearson's coefficient of correlation for every pair of variables. In the cases when the sample distribution significantly differed from the normal distribution non-parametrical Spearman's test of correlation was used to estimate the interdependence of two features. All calculations were made with the help of StatSoft program STATISTICA 7 (USA). The investigation was supported by grant DS 53 AWF Warszawa, Poland.

\section{RESEARCH RESULTS}

The results of the research are presented in Tables $1-3$. On the base of aerobic efficiency parameter values analysis in a half-year training cycle of young football players it was found that aerobic power $\left(\mathrm{VO}_{2 \max }\right)$ was significantly increased after the training period, and due to the formation of aerobic lactic acid efficiency (special endurance) dominated. The aerobic work (persistent efforts of low intensity) typical of the 1st training period (general preparation period) did not stimulate the development of aerobic efficiency parameters of 16-17 year old football players. The intensification of sport loads (league games) after $6-8$ weeks of stabilization in the field of aerobic efficiency level lead to very essential (statistically significant) reduction of the parameters of $\mathrm{VO}_{2 \max }, \mathrm{V}_{\max }$ and $\mathrm{V}_{\mathrm{AT}}$ as well as to the increase of $\% \mathrm{VO}_{2 \max }$ with simultaneous reduction of work intensity registered at the 
Table 1. Power and aerobic capacity parameter values registered in the group of 16 - 17 year old football players during a half-year training cycle

\begin{tabular}{|c|c|c|c|c|c|c|c|}
\hline \multirow{3}{*}{ Stage of training } & \multicolumn{7}{|c|}{ Parameters of oxygenic efficiency } \\
\hline & \multirow{2}{*}{$\begin{array}{c}\text { Statistical } \\
\text { parameters }\end{array}$} & \multicolumn{3}{|c|}{ Maximum oxygenic power } & \multicolumn{3}{|c|}{ On level of anaerobic threshold } \\
\hline & & $\mathrm{VO}_{2 \max }$ & $H R_{\max }$ & $\mathbf{V}_{\max }$ & $\% \mathrm{VO}_{2}$ & $\mathrm{HR}_{\mathrm{AT}}$ & $\mathbf{V}_{\mathrm{AT}}$ \\
\hline Measurement I & $\mathrm{x}, \mathrm{SD}$ & $63.18 \pm 4.71$ & $200 \pm 7.05$ & $4.51 \pm 0.25$ & $74.16 \pm 7.56$ & $174 \pm 8.16$ & $3.07 \pm 0.38$ \\
\hline Measurement II & $\mathrm{x}, \mathrm{SD}$ & $61.84 \pm 5.59$ & $195 \pm 6.25$ & $4.69 \pm 0.28$ & $75.13 \pm 5.6$ & $176 \pm 5.41$ & $3.33 \pm 0.32$ \\
\hline Measurement III & $\mathrm{x}, \mathrm{SD}$ & $63.87 \pm 4.55$ & $192 \pm 6.47$ & $4.94 \pm 0.41$ & $74.15 \pm 4.94$ & $177 \pm 5.27$ & $3.59 \pm 0.31$ \\
\hline Measurement IV & $\mathrm{x}, \mathrm{SD}$ & $58.7 \pm 4.64$ & $194 \pm 7.93$ & $4.71 \pm 0.28$ & $76.73 \pm 5.79$ & $175 \pm 7.14$ & $3.3 \pm 0.35$ \\
\hline \multirow{3}{*}{$\begin{array}{l}\text { Level of } \\
\text { significance of } \\
\text { differences }\end{array}$} & $\mathrm{I}-\mathrm{II}$ & ns & ns & ns & ns & ns & $\mathrm{p} \leq 0.001$ \\
\hline & II-III & $\mathrm{p} \leq 0.05$ & $\mathrm{p} \leq 0.05$ & $\mathrm{p} \leq 0.01$ & ns & ns & $\mathrm{p} \leq 0.01$ \\
\hline & III-IV & $\mathrm{p} \leq 0.001$ & ns & $\mathrm{p} \leq 0.01$ & ns & ns & $\mathrm{p} \leq 0.001$ \\
\hline
\end{tabular}

Note. Measurements: I — beginning of the general preparation period; II — the end of the general preparation period; III — the end of the special preparation period; IV — the end of the start period.

Table 2. Anaerobic alactic power parameter values registered in the group of 16-17 year old football players during a half-year training cycle

\begin{tabular}{|c|c|c|c|}
\hline \multirow{2}{*}{ Stage of training } & \multirow{2}{*}{ Statistical parameters } & \multicolumn{2}{|c|}{ Parameters of anaerobic capacity (non-lactic) } \\
\hline & & $\mathrm{P}_{\max 10}, \mathrm{~m} / \mathrm{s}$ & $P_{\max 30}, J / k g$ \\
\hline Measurement I & $\overline{\mathrm{x}}, \mathrm{SD}$ & $11.77 \pm 0.6$ & $10.24 \pm 0.67$ \\
\hline Measurement II & $\overline{\mathrm{x}}, \mathrm{SD}$ & $12.34 \pm 0.75$ & $10.76 \pm 0.61$ \\
\hline Measurement III & $\overline{\mathrm{x}}, \mathrm{SD}$ & $12.96 \pm 0.96$ & $11.11 \pm 0.75$ \\
\hline \multirow{2}{*}{ Level of significance of differences } & $\mathrm{I}-\mathrm{II}$ & $\mathrm{p} \leq 0.01$ & $\mathrm{p} \leq 0.001$ \\
\hline & II-III & $\mathrm{p} \leq 0.01$ & $\mathrm{p} \leq 0.01$ \\
\hline
\end{tabular}

Table 3. Anaerobic glycolytic capacity parameter values of 16-17 year old football players during a half-year training cycle

\begin{tabular}{|c|c|c|c|c|c|c|c|c|c|}
\hline \multirow{2}{*}{$\begin{array}{l}\text { Stage of } \\
\text { training }\end{array}$} & \multirow{2}{*}{$\begin{array}{c}\text { Statistical } \\
\text { parameters }\end{array}$} & \multicolumn{8}{|c|}{ Parameters of anaerobic capacity (lactic) } \\
\hline & & $\begin{array}{c}\mathbf{W}_{\text {TOT30 }}, \\
\text { J / kg }\end{array}$ & $\begin{array}{l}\Delta \mathbf{L A}_{30}, \\
\mathbf{m m l} / \mathbf{l}\end{array}$ & $\begin{array}{c}\mathbf{W}_{\text {Tот60}}, \\
\text { J / kg }\end{array}$ & $\begin{array}{c}\sum \mathbf{W}_{\text {тотз00 }} \\
\mathbf{J} / \mathbf{k g}\end{array}$ & $\begin{array}{l}\Delta \mathbf{L A}_{60}, \\
\mathbf{m m l} / \mathbf{l}\end{array}$ & $\begin{array}{c}P_{\max 60} \\
\mathrm{w} / \mathrm{kg}\end{array}$ & $\begin{array}{c}\mathbf{W}_{\text {TOт (10 s) }} \\
\text { J / kg }\end{array}$ & $\begin{array}{c}\sum \mathbf{W}_{\text {TOT }(6 \times 10)} \\
\text { J } / \mathbf{~ k g}\end{array}$ \\
\hline Measurement I & $\overline{\mathrm{X}}, \mathrm{SD}$ & $258.3 \pm 14.92$ & $9.56 \pm 2.2$ & $420.4 \pm 24.28$ & $1026.5 \pm 79.72$ & $15.4 \pm 2.91$ & $10.39 \pm 0.72$ & $102.52 \pm 6.95$ & $591.48 \pm 33.65$ \\
\hline Measurement II & $\overline{\mathrm{x}}, \mathrm{SD}$ & $271.5 \pm 15.52$ & $10.4 \pm 2.43$ & $434.3 \pm 38.47$ & $1079.07 \pm 78.4$ & $15.2 \pm 2.64$ & $10.57 \pm 0.81$ & $108.19 \pm 7.54$ & $629.59 \pm 38.85$ \\
\hline Measurement III & $\overline{\mathrm{x}}, \mathrm{SD}$ & $279.18 \pm 16.82$ & $10.82 \pm 1.52$ & $437.59 \pm 8.03$ & $1090.4 \pm 76.91$ & $15.49 \pm 2.22$ & $10.46 \pm 1.03$ & $111.89 \pm 9.44$ & $651.26 \pm 46.91$ \\
\hline \multirow{2}{*}{$\begin{array}{l}\text { Level of } \\
\text { significance of } \\
\text { differences }\end{array}$} & $\mathrm{I}-\mathrm{II}$ & $\mathrm{p} \leq 0.001$ & ns & ns & $\mathrm{p} \leq 0.01$ & ns & n.s & $\mathrm{p} \leq 0.01$ & $\mathrm{p} \leq 0.001$ \\
\hline & II-III & $\mathrm{p} \leq 0.01$ & ns & ns & ns & ns & n.s & n.s. & $\mathrm{p} \leq 0.01$ \\
\hline
\end{tabular}

AT threshold. The systole frequency at the AT threshold $\left(\mathrm{HR}_{\mathrm{AT}}\right)$ did not change in the half-year cycle. The comparison with the changes of the rest of parameters of the efficiency allows us to suggest that this parameter is not reliable for the diagnosis of aerobic efficiency of football players and its changes. The highest diagnostic value can be attributed to the speed at AT threshold which allows to estimate the intensity of work that can be done with dominating contribution of aerobic metabolism during the activity.

The analysis of value, structure and dynamics of alactic anaerobic efficiency level of the examined group of football players were carried out in the sphere of metabolism power and capacity. Table 2 presents the values of anaerobic alactic power parameters.
The estimation of anaerobic alactic acid capacity is based on the analysis of total power during 10second effort $\left(\mathrm{W}_{\mathrm{TOT}(10)}\right)$ and on the base of total work sum registered during six 10-second efforts $\left(\Sigma \mathrm{W}_{\text {TOT }(6 \times 10)}\right)$, made with maximal efficiency under constant 90-second pause between the tests.

The analysis of value, structure and dynamics of anaerobic alactic efficiency parameters in the 6-month training cycle showed that realization of special and start exercises by football players stimulated the development of anaerobic alactic power, expressed by the increase of the speed of running and maximal power achieved during the effort on cycloergometer. The maximal growth of anaerobic alactic capacity was obtained in the special and pre-start preparation period. The start period was not favourable for the changes of all parameters of the efficiency of football players. The growth of 
work value in the 10 -second test $\left(\mathrm{W}_{\mathrm{TOT} 10}\right)$ and the $6 \times 10$-second $\left(\Sigma \mathrm{W}_{\mathrm{TOT}(6 \times 10)}\right)$ test did not significantly manifest after the period of starting loads. The loads of the starting period (the 3rd training period), characterized by high intensity, did not influence the essential break of power and the increase of anaerobic alactic capacity parameters. The sphere of efficiency of 16-17 year old football players mentioned above was under constant development during the whole half-year training cycle.

The average values, the level of significance of the differences between the values of parameters showing the level of anaerobic glycolytic efficiency and speed endurance, registered in three training periods, are presented in Table 3.

The registered characteristics of parameter value changes showed that power $\left(\mathrm{P}_{\max 60}\right)$ did not change significantly. The usability of power parameter in 60 -second cycloergometric effort for the estimation of the efficiency of this kind was not suggested (because of low sensitivity). The dissimilarity of the changes in the analyzed parameters, especially $\mathrm{V}_{\mathrm{R} 150}$ and $\mathrm{V}_{150(2)}$, showed the necessity of the accuracy in the interpretation of the level. The periodically changing parameters of anaerobic glycolytic capacity during the 6-month cycle were as follows: total work during the 30 -second effort $\left(\mathrm{W}_{\text {Tот30 }}\right)$ and the sum of total work during three 60 -second efforts with a 60 -second pause $\left(\mathrm{W}_{\mathrm{TOT}}\right.$ $(3 \times 60)$. The increase of the loads of high $(\mathrm{HI})$ and very high (VHI) intensity was favourable for the development of anaerobic lactic acid capacity, that testifies the significant resources in the field of anaerobic glycolytic metabolism capacity in examined group of football players. The usefulness of the changes of anaerobic glycolytic capacity level and the changes of lactic acid concentration in blood after $30-60$ second efforts of maximal intensity in these estimations were substantiated. The changes should not be expected in the sphere of statistically significant values. The conclusions may be based on the characteristics and tendencies of value changes.

\section{DISCUSSION}

The sport level can be excluded as the factor of differentiation of the frequency of taking up the efforts characteristic of every metabolic area. The reduction of game time in the groups of younger competitors serves the maintenance of the game rate, not allowing the increase of the efforts of high intensity.
The analysis of literature sources (Boileau et al., 1983; Pessenhofer et al., 1983; Chmura, Jurasiak, 1994) shows the maximal effectiveness of the efforts at the level of $70 \% \mathrm{VO}_{2 \max }$ value. Then optimal structures of the efforts executed by football players are similar in each group in spite of the sport level. The differences concern the external signs of the abilities to work, which first of all is the speed of movement. The higher the power level of different energy sources, the higher the speed of running during the sport competition and during the active game. The higher the capacity of energy source, the higher the ability of multiple work execution of high intensity in the following efforts (Rambsbottom et al., 1988; Kolbe et al., 1995; Nicholas et al., 2000; Harley et al., 2002).

The analysis of the level of changes of the efficiency in every sphere of metabolic changes of young football players was another task of the research besides the value and structure of the training loads. The literature sources describing this problem are numerous in comparison with the literature analyzing the structure and values of training loads in football (Ekblom, 1986; Chmura, Jurasiak, 1994; Laurentowska et al., 1994; Reilly, 1994). The results of our own research indicate the significant growth of aerobic and anaerobic efficiency parameters in the special preparation period and the lack of positive transfer of realized training loads on the aerobic efficiency level in the general preparation period. It was shown that the use of increased training loads (special and start exercises) after the general preparation period evoked very fast growth of speed of running and maximal anaerobic power. The increase of anaerobic lactic capacity was observed together with the growth of power. The excessive work volume of such character reduces the majority of parameters characterizing the efficiency of football players. Most unfavorable changes are observed in the sphere of aerobic efficiency. J. Chmura (2001) paid attention to the possibility of such effect using high intensity loads. The excessive fermentation of organism is the consequence of the reduction of aerobic metabolism in the result of multiple usage of high anaerobic lactic-acid loads. Football players experience such phenomenon after two training units of speed-effort character in one microcycle (Chmura, 2001) The effect of activation of anaerobic dextrose is the reduction of energy production effectiveness during aerobic and anaerobic metabolism. As H. Liesen (1983) noticed, it brings to inhibition of the appearance 
of supercompensation phenomenon and the lack of the possibility for football players to come back to the earlier level of motor abilities (endurance and speed) and aerobic efficiency. Such state can be explained by high activation of symptomatic part of vegetative nervous system .Elongated activation creates additional complications for regeneration process and supercompensation appearance (Liesen, 1988). The reduction of aerobic efficiency by 10 $20 \%$ in the group of $16-17$ year old football players in the second part of the start period corresponds to the observations of J. Chmura (2001) who estimates the limits of such reduction by $20-25 \%$ of the initial value. The rationalization of loads selection in the area of speed endurance forming (endurance forming area loading football-players' organism to maximal degree) demands the use of the measures of current control. It is common to use the control of the frequency of the contractions of the heart for such purposes. The research in the group of 16-17 year old football players showed the low sensibility of this parameter in the response to efficiency changes, estimated on the base of the work of maximal and submaximal intensity. Similar opinions on the value analysis of frequency of contractions of the heart in the estimation of the threshold and above-threshold efforts as a general index allowing the steering of training loads selection are given by other authors as well (Liesen, 1983; Gerisch, Tritschoks, 1985; Weber, Gerisch, 1991; Chmura, 1993; Chmura, 2001). The research of H. Liesen (1983) showed that when the frequency of the heart contractions was reduced up to $120 \mathrm{cont} / \mathrm{min}$ after 6 repetitions at the intervals of $120-150 \mathrm{~s}$ between them, lactate concentration reached the value of $15-20 \mathrm{mmol} / 1$. Thus, the high level of fermentation of young football-players' organism was noticed. The results of our research confirmed the limited range of monitoring of the contractions of the heart for training load selection.

\section{CONCLUSIONS}

1. The research carried out in the group of $16-17$ year old football players showed the differentiated range of changes of the parameters characterizing the aerobic efficiency level. The tendency of increasing of $\mathrm{VO}_{2 \max }$ level was noticed during the special preparation period when the essential part of training was directed to the development of football players' special endurance. The training loads of aerobic character (persistent efforts of low intensity) typical of general preparation period was not a sufficient stimulus for the development of aerobic efficiency of 16-17 year old football players.

2. During a half-year training period it was observed that there were significant differences in the range and direction of the changes of parameter values characterizing anaerobic efficiency and speed, as well as speed endurance among 16-17 year old football players. The maximal increase of anaerobic alactic capacity was observed during special and pre-start preparation periods. The growth of parameters of maximal power and total work during short-time efforts (less than 10 seconds) on the cycloergometer was not observed. The parameters undergoing to periodical changes during a 6-month training cycle include the total work during Wingate test $\left(\mathrm{W}_{\text {тотзо }}\right)$ and the sum of total work $\left(\Sigma \mathrm{W}_{\text {TOT }(3 \times 60)}\right)$ during three 60 second efforts with a 60 -second pause.

\section{REFERENCES}

Berger, J., Harre, D., Bauersfeld, M. (1982). Fundamentals and methods of speed training. In Principles of Sports Training. Berlin: Sportverlag.

Boileau, R. A., Misner, J. E., Dykstra, G. L., Spitzer, T. A. (1983). Blond lactic acid removal during treadmill and bicycle exercise at various intensities. Journal of Sports Medicine and Physical Fitness, 23, 159-167.

Catterall, C., Reilly, T., Atkinson, G., Coldwells, A. (1993). Analysis of work rate and heart rates of associating football referees. British Journal of Sports Medicine, $27,153-156$.

Chin, M. K., Lo, Y. S. A., Li, C. T., So, C. H. (1992). Physiological profiles of Hong Kong elite soccer players. British Journal of Sports Medicine, 26, 262-266.

Chmura, J., Jurasiak, R. (1994). Changes in psychomotor performance of soccer players subjected to an exercise test Biology of Sport, 11 (3), 197-203.

Chmura, J. (2001). Szybkość w piłce nożnej. Katowice: AWF.
Dintiman, G., Ward, B., Tellez, T. (1997). Sports Speed. HKP Champaign: Illiois.

Ekblom, B. (1986). Applied physiology of soccer. Sports Medicine, 3, 50-60.

Gerisch, G., Tritschoks, H. (1985). Cooper-Test und Sprintausdauertest mit und ohne Ball im Fussball. Leistungssport, 5, 42-48.

Harley, R., Banks, R., Doust, J. (2002). The development and evaluation of task specific fitness test for association football referees. In T. Spinks, T. Reilly, A. Murphy (Eds.), Science and Football. P. 76-80. London: Routledge.

Hrysomallis, C., Koski, R., McCoy, M., Wrigley, T. (2002). Correlation between field and laboratory tests of strength, power and muscular endurance for elite Australian Rules footballers: $4^{\text {th }}$ World Football Congress of Science. Sydney, Australia (pp. 81-85).

Kolbe, T., Dennis, S. C., Selley, E. (1995). The relationship between critical power and running performance. Journal of Sports Sciences, 3 (13), 265-269. 
Laurentowska, M., Rychlewski, T., Jastrzębski, A. (1994). Ocena wydolności tlenowej oraz beztlenowej zawodników I-ligowego zespołu piłki nożnej. Trener, 1 (21), 44-51.

Liesen, H. (1988). Schmelligkeitsansdaner — Spieler werden kaputt trainiert. Fussballtraining, 6, 24-30.

Liesen, H. (1983). Training ko nditioneller Fähiykeiten in der Vorbereitungsperiode. Fussbelltraining, 5, 27-32.

Nicholas, C. W., Nuttall, F. E. Williams, C. (2000). The Loughborough intermittent shuttle test: A field test that simulates the activity pattern of soccer. Journal of Sports Sciences, 18, 97-104.

Pessenhofer, H., Schwaberger, G., Sauseng, N., Kelner, T. (1983). Laktatkinetik und aerob-anaerober Übergang und Gsundheit. In Deutscher Sportärztekongress 1982. Deutscher Ärzte-Verkag Köln. P. 157-162.

Ramsbottom, R., Brewer, J., Williams, C. (1988). A pro- gressive shuttle test to estimate maximal oxygen uptake. British Journal of Sports Medicine, 22, 141-144.

Reilly, T. (1994). Physiological profile of the player. In B. Ekblom (Ed.), Football (Soccer). London: Blackwell Scientific. P. 78-94.

Shepard, R., Astrand, P. O. (1992). Endurance in Sport. Oxford, U.K. Blackwell Scientific.

Spinks, W. (Ed.) (2002). Science and football IV. London: Routledge. P. $81-85$.

Telford, R. (1991). Endurance training. Better Coaching F. Pyka (Ed.). Australian Coaching Council. P. 125-134.

Weber, K., Gerisch, G. (1991). Schnelligkeistest im Leistungsfussball. TW Sport+Medizin, Karlsruhe, 4, 120-125.

Wierchoszanskij, J. W. (1985). Programirowanije i Organizacija Trenirowocznogo Procesa. Moskwa: Fizkultura i Sport.

\title{
LABORATORINIAIS METODAIS NUSTATYTAS JAUNŲJŲ FUTBOLININKŲ AEROBINIS IR ANAEROBINIS PAJĖGUMAS PER PUSMEČIO PRATYBAS
}

\author{
Szmatlan-Gabrys Urszula ${ }^{1}$, Ozimek Mariusz ${ }^{2}$, Szczerbowski Marek ${ }^{3}$ \\ Varšuvos kūno kultūros akademijal, Varšuva, Krokuvos kūno kultūros akademija ${ }^{2}$, Krokuva, Katovicu \\ kūno kultūros akademija ${ }^{3}$, Katovicai, Lenkija
}

\section{SANTRAUKA}

Futbolo rungtynių metu dideli poveikị žaidimo veiksmingumui turi žaidèjų greitumo-jègos ir greitumo - trumpo darbo ištvermès savybès. Jos priklauso nuo anaerobinio energijos gamybos būdo.

Tyrimo tikslas - nustatyti šešių mėnesių pratybų krūvio struktūros poveikį jaunujų futbolininkų aerobiniam ir anaerobiniam pajègumui. Buvo tiriami 9 šešiolikamečiai žaidèjai ir $18-17$ metu amžiaus. Tyrimai atlikti parengiamojo laikotarpio pabaigoje ir varžybų pradžioje. Buvo atlikti trys tyrimai: pirmas eksperimento pradžioje, antras - po 3 mènesių, trečias - po 6 pratybų mėnesių. Buvo tirta kraujotakos ir kvèpavimo sistemų reakcija i pamažu didèjantį fizini krūvị, Vingeito testo metu, reakcija ị mažos trukmès fizini krūvị, darbo galingumas. Matuota laktato koncentracija.

Tyrimo duomenys parodè, kad 16-17 metų futbolininkų aerobinis pajègumas yra skirtingo lygio. Aerobinès pratybos, kurios vyko per pirmą treniruočių etapa, nepaveikè jaunujų futbolininkų aerobinio pajëgumo. Po 6-8 savaičiu pratybų, kurių metu vyravo žaidimo veikla, pastebètas didelis $\mathrm{VO}_{2 \max }$, deguonies suvartojimo ties anaerobinio slenksčio riba rodiklių sumažèjimas, tačiau $\% \mathrm{Vo}_{2 \max }$ rodiklis ties anaerobiniu slenksčiu padidèjo sumažèjus darbo galingumui.

Parengiamojo laikotarpio pabaigoje pastebètas maksimalaus deguonies suvartojimo didèjimas, nors pagrindinis pratybų uždavinys buvo gerinti jaunujų futbolininkų specialiają ištvermę. Anaerobinis alaktatinis pajègumas padidejo statistiškai patikimai $(\mathrm{p}<0,001, \mathrm{p}<0,01)$ tiek per bendrojo, tiek per specialiojo rengimo laikotarpius. Varžybų laikotarpis nėra palankus metas bandyti gerinti jaunujų futbolininkų funkcinio pajègumo rodiklius.

Maksimalioji jèga ir trumpo darbo galingumas šiuo laikotarpiu patikimai nepadidèjo. Patikimai padidèjo darbo galingumas Vingeito testo metu ir suminis bendrasis darbo galingumas atliekant $3 \times 60$ s fizinį krūvị. Laktato koncentracijos pokyčiai po $30-60 \mathrm{~s}$ maksimalaus darbo buvo pastebèti.

Raktažodžiai: aerobinis pajègumas, anaerobinis pajègumas, pratybos, futbolas.

Gauta $2007 \mathrm{~m}$. balandžio 3 d.

Received on April 3, 2007

Priimta $2008 \mathrm{~m}$. vasario $20 \mathrm{~d}$.

Accepted on February 20, 2008
Urszula Szmatlan-Gabrys

The Jozef Pilsudski Academy of Physical Education in Warsaw

(Varšuvos J. Pilsudskio kūno kultūros akademija)

00-968 Warszawa, ul. Marymonska 34,

Polska (Lenkija)

Tel 0-22 834-04-31

E-mailwf@awf.edu.pl 